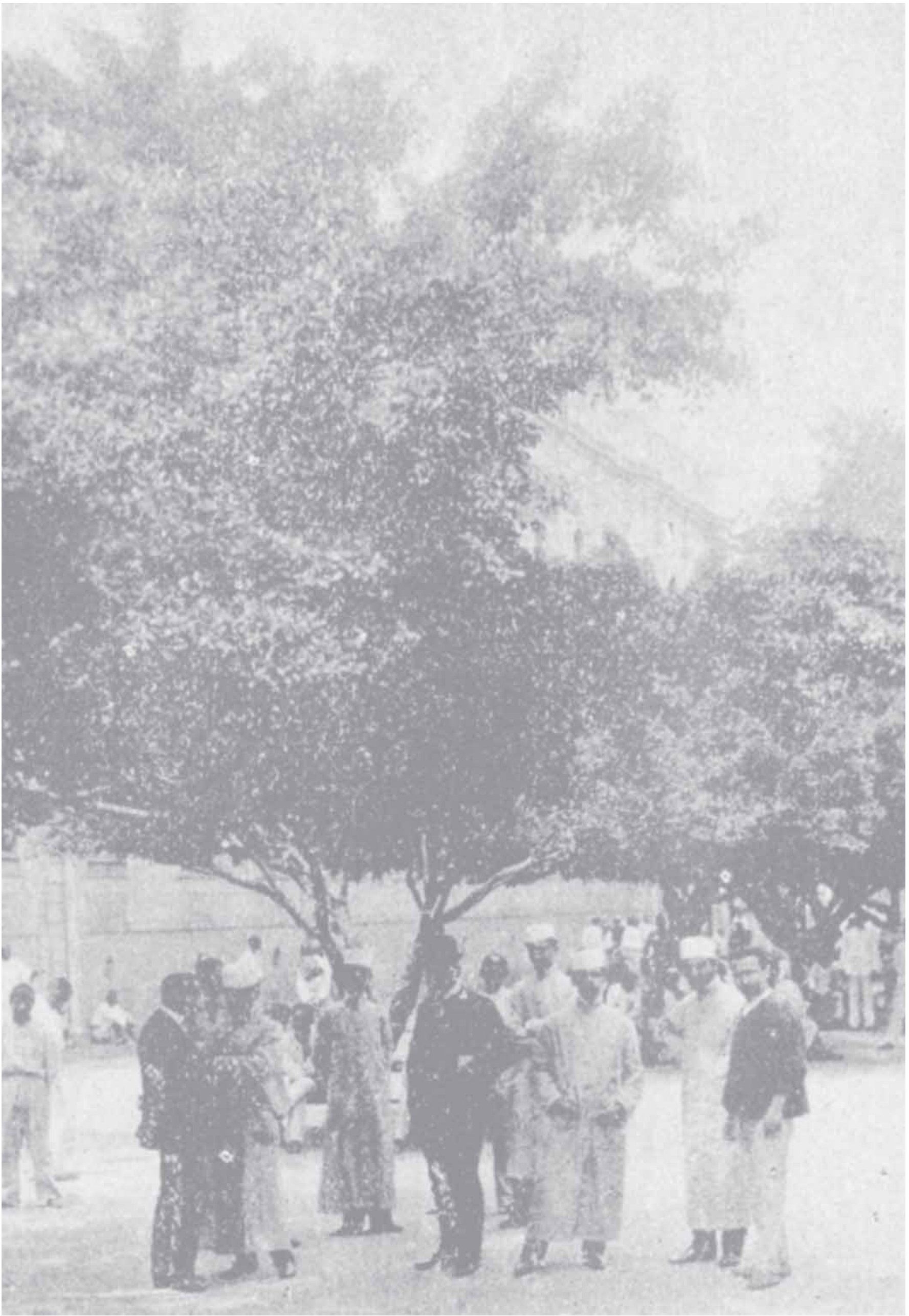





\title{
A paranoia e as síndromes paranoides
}

\author{
Pelos doutores Juliano Moreira e Afrânio Peixoto \\ (Do Hospício Nacional de Alienados)
}

Arquivos Brasileiros de Psiquiatria, Neurologia e Ciências Afins, Rio de Janeiro, n.1, 1905, p.5-33

\section{u u UUU}

De Westphal a Mendel o conceito da Verrücktheit ou sua crisma helênica - a paranoia - tem vindo tão diversamente modificado, que se realizou a predição de Pelman: acabamos por nem mesmo nos entender. Cada alienista tem vistas pessoais do assunto; e ora se descrevem doenças diversas com o mesmo nome, ora enfermidades idênticas com outros nomes, ora, finalmente, algumas designações qualificativas precisam espécies mórbidas que se não podem conter dentro do mesmo gênero. É um verdadeiro estado de Babel ou confusão psiquiátrica, em que a gente se arrisca, no fim, a não sair à luz com uma ideia definida. De estados agudos e transitórios a ideias fixas ou obsessões, de conceitos arrazoados em sistema a demências com ideias residuais de grandeza ou perseguição, até mesmo estados em que tais delírios faltam por completo, tudo tem sido descrito sob a mesma rubrica, sendo corrente ouvir-se falar de paranoia aguda, rudimentária, persecutória, ambiciosa, religiosa, erótica, masturbatória, indiferente, até. Por outro lado, uma enfiada de designações francesas, alemãs, inglesas, italianas, todas sem sentido limitado, abrigam veleidades diagnósticas de espécies afins, completando o labirinto.

A dificuldade toda proveio de terem servido de base ao juízo psiquiátrico síndromes mentais de perseguição, grandeza e suas variantes, de modo que, fosse qual fosse o estado em que aparecessem, sem mais indagar da etiologia, da patogenia, da sintomatologia, dos caracteres das ideias ou delírios - consistência, coesão, arrazoamento, persistência ou não de um entendimento lúcido - o nome paranoia serviria para abrigá-los em sua latíssima compreensão. Os casos da chamada paranoia aguda são tirados entre os delírios tóxicos, autotóxicos e infecciosos, provindos do alcoolismo, saturnismo, esgotamento, discrasia, uremia, sífilis, malária, etc. A paranoia rudimentária é o outro nome das obsessões e ideias fixas, episódios da degeneração, que nenhuma aprendia clínica tem com o fato como discutido. A paranoia rudimentária se provê nas diversíssimas doenças em que sobre um fundo demencial de senilidade, esgotamento ou degeneração, surgem concepções delirantes, absurdas ou incoerentes.

N.E. - Sobre este artigo, ver "Ordenando a babel psiquiátrica: Juliano Moreira, Afrânio Peixoto e a paranoia na nosografia de Kraepelin (Brasil, 1905)”, de Ana Maria Galdini Raimundo Oda, neste número de História, Ciências, Saúde Manguinhos. 
Foi destas vistas aleatórias, caos que a imprecisão do critério clínico e filosófico criou através dos psiquiatras contemporâneos, que o professor Emil Kraepelin buscou a palavra paranoia, - o termo hipocrático que tão bem chama um tipo mórbido determinado (paranoein, pensar errado, pensar de viés), para atribuí-lo a quem consoante. São suas ideias que propagamos, procurando na descrição e no exemplo traçar o limite com os delírios expansivos e os de perseguição, e outros que tais, delusões, para usar o expressivo vocábulo britânico, ou, se melhor valem, ideias, delírios ou simplesmente síndromes paranoides, epifenômenos de quase todas as formas de doença mental. Como a observação consente independências, referimo-nos às nossas, tirando no correr ilações que nos pareceram justificadas.

\section{Etiopatogenia}

Contrariamente às estatísticas anteriores que chegavam a atribuir, em asilos da Europa, 70 a $80 \%$ à paranoia (Weygandt), ou às do Nosso Hospício Nacional de Alienados, em cujos relatórios se acham sempre mais de $25 \%$ de tais doentes, desgarro provindo de se chamar assim a todas as doenças mentais em que as delusões existem - a paranoia é uma doença rara, concorrendo com 2 a $4 \%$ (Kraepelin) para a população dos asilos. O número que encontramos, $2,5 \%$, está incluído nesta avaliação. Deve-se, porém, dizer que a maior parte dos paranoicos escapa aos hospícios, ou porque se não tornem incompatíveis com o meio pela acuidade de suas concepções, ou porque sua orientação na vida tome rumo que isso evita, o fato é que com eles nos encontramos frequentemente, dos casos frustros àqueles ainda equilibrados, que são chamados de excêntricos, vaidosos, originais, etc. As mulheres são evidentemente mais poupadas pela doença; isto talvez obedeça a circunstâncias de valor que restringe no momento sua vida social; voltaremos ao caso.

A doença irrompe na idade adulta: o termo de 24 a 40 anos, é exato; aliás é o período intenso de luta entre a personalidade e o meio, e, segundo o nosso modo de ver, raríssimo será que conflitos, antes do momento do combate ou depois da capitulação, venham a ser a causa ocasional da enfermidade.

No tocante à causa da paranoia há uma tendência geral para incriminar a degeneração - esse mal feito da herança próxima, ou mesmo, mais recuada, do atavismo.

Esta doutrina de degeneração, desde que se apresentou a Morel e veio nos tempos recentes a se assenhorar da psiquiatria, não encontrou ainda senão submissões irrefletidas, que se vão sucessivamente imitando, porque é mais fácil pensar com os outros do que observar consigo mesmo. Longe de nós, seja dito logo, negar-lhe a verdade incontestável: ela existe, ela é profunda, a ela se deve grande parte de nossas misérias. Mas não é menos verdade que muito se tem abusado de sua fama, exagerando capitalmente a sua ação. O critério com que em psiquiatria hodierna, de origem latina sobremodo, se aponta à degeneração - três ou quatro estigmazinhos irrisórios um lóbulo aderente da orelha, um septo desviado do nariz, um queixo mais comprido, uns dentes mais separados - a austeridade com que lhe esfumaçam as consequências, permitindo de um lado supor degenerada toda a espécie humana, marcando-lhe do outro, como destino inelutável, o hospital, o manicômio, a prisão, a esterilidade e a extinção, fazem crer que chegamos a um finis hominis irremediável. Deslembram-se esses médicos acanhados de que a degeneração que vem por toda a parte é uma já estereotipia diagnóstica, quando não seja uma simples ecolalia de designação, e que, para contrapor aos casos sizudamente comprovados de derrancamento somático 
do indivíduo, há, a todos os momentos, esta obra de regeneração da espécie que suprime o indivíduo, quando não logra corrigir-lhe as aberrações, integrando, no futuro, o tipo comum.

Depois, a herança que explica a degeneração e outros malfeitos mais parece ter sido gravada de imaginárias culpas. Não há muito tempo todas doenças as eram hereditárias: para tomar uma só delas, a tuberculose, vimo-la sofrer sucessivas interpretações etiológicas: primeiro herdava-se a tuberculose, depois falou-se na heredotuberculose tardia, mais tarde na predisposição... . Agora, Berend demonstrou-o, filhos de héticos até, ninguém traz originariamente a semente de Koch e só mais tarde, nós todos, na vida, vamos ficando mais ou menos tuberculosos. Assim aqui. Esquecemo-nos por completo do meio em que vivemos uma vida inteira de combates e reações incessantes para tudo atribuir a umas tantas metafísicas da biologia, ainda sem provas. A não ser compreendendo na expressão herança aquele sentido latíssimo que um de nós já lhe emprestou, falando de herança sociológica, que mais prepondera na gênese do adultério que a biológica, a não ser talvez estendendo mais ainda ao conjunto de condições físicas e sociais ambientes, em uma palavra originárias ou consequentes e que nos influenciam em nossa derivação mesmo, somos forçados a fazer aqui umas tantas restrições ao sentido estreito do conceito, sobre o assunto que nos ocupa.

Quanto ao atavismo... pior ainda. Esta expressão tem vindo por aí além, imputada de significados aleatórios; sobremodo os autores italianos têm, em matéria de psicopatologia, abusado dela: serve-lhes pra tudo, coisa alguma há nestes domínios que eles não expliquem, do crime à loucura, por este termo vazio do sentido, bordando em torno uma teia engenhosa com anedotas arqueológicas e históricas muito suspeitas. Tanzi e Riva fizeram-se seus patronos na etiopatogenia da paranoia, sob pretexto que a evolução intelectual na humanidade se faz no sentido de um subjetivismo decrescente, o Eu subordinado, assim, mais e mais, ao mundo exterior; seria, pois, atávica essa regressão à ancestralidade egoísta e o paranoico "um documento do atavismo".

$\mathrm{O}$ atavismo é uma mera fantasia. Bombarda disse-o em uma palavra: é um mito. De fato, não nos parecemos com os nossos avós porque um misterioso atavismo isto permitiu, mas porque nos parecemos com nossos pais, com nossos filhos, que se parecerão entre si e com esses recuados antepassados: e se no detalhe diferimos uns dos outros é porque na variação evolutiva ou mutativa, através do tempo, nos vamos adaptando a esses novos modos de ser. Sempre, em suas qualidades fundamentais, a humanidade foi a mesma e a mesma seria, se a vida mesológica - física e civil nos não viesse deformando, alterando, adaptando ao ambiente do mundo. Cada criança que nasce é socialmente comparável ao primeiro homem; o Eu lhe vem hipertrofiado, e, a julgar pela ampliação possível, sem as restrições modificadoras, cada uma seria comparável a um louco ou a um criminoso; é a educação, a disciplina, a cultura, que as submetem, modificam, adaptam, dando-lhes por fim essa identidade social, de que fala Tarde.

É, pois, escusado ir buscar exemplos de egofilia em áreas remotas, tão mal conhecidas, e, por isso mesmo, tão mal julgadas, para os fazer ancestrais de cada aberração atual. Temos, todos os dias, no presente, a apreciação desse subjetivismo exagerado, mas absolutamente normal, e que foi o de todos nós: é a afirmação mesma da personalidade. A ficção de Stirner - do único e sua propriedade - é um cliché de nossa psicologia íntima. $\mathrm{O}$ altruísmo não é uma aquisição definida e já somática: é apenas uma espécie de contrato a que nos submetemos tacitamente ao partilhar a vida social, que nos impõem; e não são raras as infrações do pacto. 
No paranoico houve apenas a persistência desse originário modo de ser, por deficiência de educação, de treinamento, de cultura...: o subjetivismo primitivo cresceu com o indivíduo, vive com ele e é a seu través que ele julga o mundo exterior. Nós também o julgamos, mas nós somos, como as lentes, corrigidas das aberrações: eles não, não têm correção alguma, e eram, e cresceram, e ficaram vendo, pois, tudo diferentemente. O mundo não se adapta a nós, porque nós bem podemos ver que esta adaptação não é possível: conformamo-nos e nos adaptamos a ele; o paranoico não pode ver assim: o mundo não se adapta a ele, porque o mundo está errado, e tenta corrigir, isto é, adaptar tudo à sua vontade porque jamais pode pensar em si para o mundo, mas no mundo para si. É uma pura ilusão supor que sejamos todos moldados por herança à vida das sociedades. Este contrato tácito, que todos temos, não se herda, faz-se através dos primeiros anos com a convivência, a lição, a experiência; vem sem violência, porque vem desde o começo, insensivelmente e inconscientemente, pelo próprio fato de viver no meio civil. Evolução, civilização, educação são equivalências correspondentes à espécie, raça, indivíduo; exista a espécie, diferencie-se a raça, reúnam-se os indivíduos em sociedade, e pela própria força que os anima estes destinos se cumprirão. Assim para frente: para trás a observação é idêntica. Tenhamos, pois, a boa fé de procurar em nós principalmente no meio em que vivemos as causas dos nossos males: não cremos palavras sonoras que contentam a ignorância ociosa, mas não bastam à curiosidade persistente.

A paranoia é originária. Isto quer dizer que a educação permitiu crescerem livremente os germes de autofilia egocêntrica, favoreceu-os, ampliou-os, de sorte que, assim preparado, os atritos inevitáveis com o meio social vão ser motivos ocasionais do desequilíbrio definitivo desse, instavelmente equilibrado no meio, que é o paranoico. Compreende-se facilmente que deve haver gradações extensíssimas nesta escala, para o que concorrem as variações de terreno, as múltiplas circunstâncias da criação educativa, as diversíssimas vicissitudes ocasionais que fazem da anomalia surgir a doença. A primeira parte se explica por esta noção assente da degeneração, ainda entretanto não delimitada por não ter esclarecida sua intimidade mórbida: não há negar, porém, ser a degeneração, a real degeneração, a leira preparada para o cultivo de todas as aberrações. O segundo trecho, o principal, com certeza, sofre como as outras variações tão extensas que, se pode dizer, por ele, as gradações da paranoia são infinitas: basta considerar as da vaidade, da presunção, da jactância, espécies abortadas ou frustras da doença, até as formas delirantes e alucinatórias, para medir a amplitude das variações.

O momento tem importância capital, porque, sem ele, o anômalo atravessa a vida sem sobre si chamar a atenção do médico; o meio familiar, os seus íntimos, os que o conhecem ou têm relações, sofrem-lhe as imperfeições de caráter, o manicômio não o receberá porque não houve uma causa ocasional que lhe promovesse o desequilíbrio, o transvio, isto é, o delírio. Olhando-se para a vida com uma certa acuidade descobrem-se destes indivíduos que se poderiam chamar temperamentos ou caracteres paranoicos; não são predispostos porque a anomalia já existe, falta apenas a irrupção. Entre outros muitos temos um exemplo bem frisante: trata-se de um homem de valor, que exerce função social elevada, tendo subido a ela por merecimento, mas sempre com bastante facilidade; é louvado no seu círculo, porque tem valor, entretanto é um deprimido, queixa-se amiúde da indiferença e da hostilidade do meio, da falta de quem o compreenda, de um conjunto de circunstâncias antagônicas que escapam a todo mundo e que são mesmo imaginárias ou antes pararreais. O motivo está em que sua autofilia, seu egocentrismo são imensamente 
hipertrofiados: as facilidades que encontrou na vida, as deferências que o cercam por toda a parte, a nomeada do público, são insuficientes para o seu amor próprio, que se julga credor de imensamente mais; o que lhe vem, fortuna para tantos outros de igual mérito, basta-lhe apenas para não ser um revoltado ativo, mas não impede de ser um descontente e um queixoso. Se esse indivíduo tivesse encontrado uma sorte adversa, se no seu caminho se antolhassem trabalhos, se fosse vítima de uma injustiça, sua anomalia não atravessaria a sua vida como o faz, na lamúria da queixa passiva, apenas: seria o perseguido dos manicômios, exibindo sua expansiva autofilia delirante e a reação consecutiva das supostas ou reais violências sofridas.

Esses caracteres paranoicos são muito comuns na vida social; são deles que se sorteiam os paranoicos que estudamos nos manicômios. Alguns mesmos já começaram a sê-lo no hábito ordinário. Este outro exemplo é interessante sob este aspecto: - R. foi uma criança amimada extremamente pelos pais; foi sempre julgado um prodígio de inteligência e discernimento no meio doméstico, mostrado, exibido, insuflado, como tal, pela família. Cresceu um pequeno déspota imperioso, convencido de sua superioridade, sempre obedecido, satisfeito, adorado. Fez exames medíocres, porque fez medíocres estudos, mas isto foi sempre explicado como inveja dos discípulos e perseguição dos mestres. Instável, vário, quer tudo e não sabe querer nada. Sonha grandes feitos, e como as letras são difíceis, bota-se à ação. Há de ser soldado, salvar a pátria: para isto urge reformar o exército. Escusado é dizer que os pais incitam e insuflam estas ideias paranoicas. Vem ao Rio matricular-se na Escola Militar; não encontra vaga. Como para a matrícula preferem-se os militares, um tio, pessoa política criteriosa, convence-o de que deve sentar praça e lhe obtém uma situação de favor no Quartel General, como escriturário; mas aí há hierarquias e o aiglon vê-se subalterno de cabos e sargentos e na primeira feita revolta-se, indisciplina-se e é preso. Este fato natural é tomado como uma calamitosa injustiça. Vocifera, pragueja, insulta, debate-se. O tio intervém e com as autoridades militares consegue fazer supor um acesso de loucura, enviar o rapaz ao Hospício com baixa do exército. O pai vem buscá-lo e já o encontra calmo e moderado. Volta à Bahia e, ao ouvi-lo, parece que sua história banalíssima de má criação indisciplina e castigo, foi um feito sublimado, que a história há de vingar. Ele mesmo se chama "o novo Dreyfus". Como é preciso atribuir o mal a alguém, presenteia o tio com a autoria, tem um punhal e há de vingar-se do opróbrio..., "chegará o dia em que sua ação há de fazer-se sentir neste país..., fará isto..., fará aquilo”. Os seus pais pasmam, admiram, aplaudem-no e o protegem. Um dia, mais tarde, quando lhe faltarem e sentir então o primeiro embate sério da vida, o delírio existirá. Mas já de há muito o paranoico começou.

Existe, pois, um período prodrômico ou de elaboração da paranoia, propriamente dita; numa fórmula breve, aqui está a marcha escalar para este fim.

1․ Primitiva e originária autofilia: sentimento inato e fundamental da personalidade - não corrigida e adaptada ao meio, antes incrementada pela educação defeituosa: egocentria resultante.

2ํㅡㄹ Inadaptabilidade correspondente entre o indivíduo e o meio: interpretação como hostilidade pessoal.

3ำ Reação contra o meio: início das perturbações aparentes. Perseguição ativa ou passiva, ou ativa-passiva, mais comumente. 
Sobre este terceiro ponto alguma coisa há a dizer. Em geral o paranoico aparentemente começa perseguido, isto é, em perseguição passiva; estudados, porém os casos em sua elaboração, verifica-se logo, a um primeiro exame, que um outro estágio existiu anteriormente, muito mais longo, em que o paranoico, em sua reação contra o meio desacorde, rompeu as hostilidades, pondo em prática a perseguição ativa, sendo, em uma palavra, um perseguidor ordinário. Como consequência forçada, real ou imaginária, é que a segunda fase se instala e temos um perseguido em observação. Já nos referimos a este desacordo profundo entre o meio e o paranoico, por inadaptabilidade deste e que se manifesta exatamente pelas reações que chamamos de perseguição ativa. Estão ainda longe dos manicômios: são estas suscetibilidades extraordinárias, estas vaidades irritantes e irritadas, estas intransigências descabidas e por isso mesmo provocadoras de reações correlatas, muitos desses chamados maus maridos, parentes, vizinhos, colegas, cidadãos, que chegam até a incompatibilidade absoluta com a sociedade. É daí que, sequestrados, começa o período de observação no manicômio: o indivíduo é então um perseguido, muitas vezes real e justamente perseguido; para ele, porém, sempre e desmedidamente violentado. Mas é preciso não esquecer que houve uma fase anterior, em que a perseguição existiu também, não sofrida de fato, ou imaginariamente, pelo doente, mas exercida por ele: foi a de perseguição ativa. Do perseguido passivo sai ou nele mesmo se enxerta o perseguidor, reacionário desta feita, realizando aquele tipo, à sociedade descrito, depois de Lasègue: o perseguido perseguidor.

Roto o equilíbrio, a vida do paranoico é esta eterna luta de ação e reação incessantes, que transformam no mais incômodo e mais perigoso dos insanos. Numa faina irrequieta, falando, movendo-se, escrevendo, argumentando, ou concentrando, remoendo pensamentos, criando e rebentando objeções, sempre preso nas malhas de uma oposição a tudo e a todos, porque tudo the é hostil, é verdadeiramente surpreendente como atravessem anos e anos sem considerável depauperamento da inteligência.

É uma ilusão completa esta, esquematizada por aí, de atribuir ao paranoico fases bem delimitadas de perseguição e grandeza: de fato, nos casos que assim devem ser chamados, nada existe de semelhante. A grandeza mesma do paranoico está longe de ser o que se tem descrito: é uma grandeza razoada quase, pelo menos possível, derivada unicamente de sua autofilia e seu egocentrismo; o que ele possui de maior e de melhor é ele mesmo, são suas qualidades, suas capacidades, seus direitos. Está, pois, muito distante dessas concepções falsas até o absurdo, que são produtos dos erros sensoriais surgidos num terreno, em que a consciência se enterra na demência. Depois, esta autofilia não tem fase, é perene, vive e é o arcabouço mesmo do paranoico: as perseguições que exerce ou que sofre vêm e atingem esta sua intimidade mesma, e é por ela que ele reage, que se alucina, e que delira.

\section{Sintomatologia}

Já dissemos como a autofilia era o fundamento mesmo da paranoia: e é da inadaptabilidade desse meio externo, em que vive, ao seu Eu desproporcionado, que os primeiros conflitos surgem e o desequilíbrio se opera, mais ou menos rapidamente. O paranoico não cede as suas prerrogativas voluntariosas, e, contrariado em sua ideia, esta se fixa, cada vez mais profundamente, no seu ânimo. O meio tampouco se pôde afeiçoar às exigências tirânicas de sua vontade e a reação que oferece, a princípio passiva, é imediatamente recebida com uma hostilidade. E começa o episódio 
que vai acabar no manicômio. O reconhecimento dessa hostilidade assim interpretada, ou melhor sentida, produz em certos deles reações depressivas, de humor irregular, de indefinido mal estar, acompanhado de inapetências e de insônias.

A primeira reação mental de defesa às supostas hostilidades é uma suscetibilidade extrema que chega à suspeição completa: tudo assume para eles um ar agressivo e nada é indiferente às suas preocupações. Fazem passar pelas suas pessoas todas as coordenadas do mundo: sentidos abertos para o exterior, critério pejorativo para julgar todas as impressões recebidas, os mínimos atos, as palavras mais insignificantes adquirem uma intenção e uma alusão. Por isso vivem, de então, sempre em guarda. Esta hiperestesia do Eu é tão afinada que não lhe escapa coisa alguma de que possam tirar uma inferência autorreflexiva. Um dos nossos doentes, P., ao ler um dia um jornal o anúncio do mosquiteiro Dixie, indignou-se porque cuidou ver uma irrisão lançada de público a uma parenta, cujo pseudônimo era homófono. Outro, A., vive a ler jornais, destacando palavras e epítetos que supõe todos referentes a si, sob o disfarce de artigos banais e das referências a terceiros. O primeiro que se cuida perseguido por frades e ordens religiosas, não se contém que não reaja, quando, em meio de uma conversação ordinária, se intercalam palavras como ordem, quadro, que ele supõe se referirem às suas concepções - "já estás na ordem, hás de ir para o adro", etc. - como já lhe disseram suas alucinações.

Desta sorte, se a reação vem imediata, eles procuram um abrigo mais seguro; por isso, não podem ficar parados em lugar nenhum, são andarilhos; quando não podem mudar de terra, mudam de bairro, mudam de casa, mudam de quarto, mudam de hábitos. O nosso doente, P., não se podendo mais desalojar de uma casa a que foi ter, por condescendência da diretoria do Hospício, percorria, com a mesa de escrita onde elaborava seus intermináveis protestos, queixas, apelações, todos os cômodos da habitação e por toda a parte as importunações, os remoques, as injúrias o acompanham.

Uma motivação explícita, sua ideia contrariada e tornada fixa, promove e instala definitivamente a perseguição com todo o seu cortejo de circunstâncias agravantes, endógenas e exógenas, de alucinações e falsas interpretações, - rebatidas na suposta agressão promovida na desforra correlata, num círculo vicioso eterno. Nesse caminho nem mesmo carece mais adiante de quem lhe sirva de oponente: o Eu paranoico, desequilibrado, se basta: vive numa ruminação contínua, é um longo diálogo em que há um interlocutor silencioso que opõe dúvidas e restrições débeis, e o doente propriamente, que fala às vezes alto, imperativamente, rebatendo com vantagens as dúvidas autossugeridas.

Fundamento do Eu paranoico, a autofilia egocêntrica promove nestes estados de desequilíbrio, endogenamente, uma afloração magnífica de ideias de grandeza. Sentem-se superiores em origem, qualidades, merecimentos. Quando não é por um fenômeno já longamente processado da falsificação da memória, por uma interpretação silogística, eles adaptam o que são ao que supõem deve ser. Um que nos falava em majestade, V., dizia ter em perspectiva uma herança de quatro mil contos e ser filho do Duque de Caxias: indagado como tinha um nome de família diferente do marechal, apelou para um nascimento espúrio e honra-se dessa proveniência. Um outro, M., escreveu um longo memorial para provar a razão de ser de suas suspeitas de ordem régia: o pai, um pobre camponês em Portugal, ao morrer, chamou-o e disse-lhe que se fosse apresentar ao elrei D. Luiz I; muito mais tarde, desavindo com a mãe, esta, num momento de raiva, dissera não ser ele seu filho... tanto bastou; mais tarde, quando se instalou a doença, reconstituiu a história e com 
esses dois ditos fez o seu romance, e é um filho do rei do Portugal, enjeitado, talvez, na província; procura apurar o porquê desse drama.

Têm sempre grandes exemplos a invocar e magnas empresas a exercer; "Não é de estranhar", nos disse um, C., "que tendo estudado matemática, queira ser agora dicionarista: Herbert Spencer foi engenheiro e acabou filósofo". Outro, o P., escreve livros copiosos extraídos da enciclopédia Larousse, que afirma depois os melhores tratados no gênero. O C., quer fazer um dicionário de sinônimos, porque não encontrou nos existentes em português algumas palavras, é uma lacuna na língua que ele vai encher. Repete frequentemente ainda o nosso doente, A., que finda a sua reclusão, em um grande volume de 3000 páginas, se vingará dos que o perseguem - "todos os seus inimigos serão confundidos, o exemplo será tremendo, e o mundo se espantará”.

Os seus merecimentos, principalmente os intelectuais são excepcionais: jactam-se de poetas, pintores, arquitetos, técnicos de toda a ordem, incomparáveis, e citam triunfos e vitórias e calculam o quanto das indenizações a receber no dia da liberdade, quando a justiça reparadora vier.

A. nos diz frequentemente: "dia virá que minha estrela brilhará belíssima".

Do seu próprio mal o Eu autofílico tira conceitos enlevados: o mesmo acima nos disse, uma feita: "a minha estada aqui (no Hospício) é um monumento de bronze imperecível: significa que os meus inimigos para me tirarem a liberdade tiveram de se valer do Presidente da Federação, do Supremo Tribunal, do Ministro da Justiça, do Chefe de Polícia, Diretor e Médicos deste manicômio, de todo este povo de enfermeiros, guardas, soldados, para me obrigarem a estar aqui - e isto contra um só homem! Esse homem deve ser por força extraordinário!....”

Finalmente, o Eu autofílico eleva-se tão absurdamente no seu conceito que perde, inconscientemente, a noção da relatividade de sua situação no meio.

É assim que, não contentes em serem mais inteligentes, mais nobres, mais valorosos, mais dignos que os outros homens, eles se cuidam, às vezes, com direitos excepcionais: é uma lesão da identidade social, que todos normalmente sentem. Um dos nossos doentes, o A., apaixonado por uma senhora casada que o repele, cujo marido lhe bateu, tentou várias vezes invadir seu domicílio, porque, diz ele, "o amor tem os seus direitos" e se julga superior ao marido e aos amantes que atribui a ela. O outro, P., cuja observação vai diante, casado, viva ainda a mulher, não tendo havido nem podendo haver anulação de casamento, nem permitindo a nossa lei o divórcio, não só se considera desquitado, como se revolta contra quem não o considera assim, legal e moralmente.

A ideia fixa que serviu de eixo às concepções paranoicas é de uma resistência que nenhum raciocínio, nenhuma evidência, por mais imponentes ou suasórios, consegue demover.

O nosso doente, P., apaixonado loucamente por uma menina, escreve-lhe amiúde, registrando as cartas. Como a amada jamais aparecera, nem respondera às missivas, imputava ora ao correio, com grandes adjetivos pejorativos, ora aos seus inimigos, o desvio da correspondência: a rapariga não recebia suas queixas: estava claro! Um dia o correio fornece-lhe um maço de recibos assinados pela destinatária: nem a esta evidência cedeu, e dias depois, triunfante confessava a todo o mundo que a firma dos recibos "era provavelmente, era com certeza falsificada". E reintegrou-se na confiança de seu amor insano.

Entretanto, as concepções subsidiárias são a incoerência mesma: o paranoico para manter a sua premissa falsa, mas irredutível, lança mão de todos os argumentos, meios, ideias, repele-os todos imediata ou sucessivamente, para retomá-los em seguida, porque em ninguém confia, e tudo lhe inspira suspeição. Quem o analisar sob este aspecto, encontrando o terreno movediço 
dessa inconstância, pode supor mal dessas tão faladas, e exatas, coerência e fixidez paranoicas: é que estes atributos são somente do eixo mesmo das concepções doentias, da ideia paranoica persistente e profunda.

A percepção das impressões externas persiste perfeita durante muito tempo; pelo menos são raros os erros sensoriais: contam-se as alucinações, do ouvido muito principalmente, os falsos reconhecimentos ou ilusões, da vista sobretudo, e as interpretações delirantes, de toda ordem. As alucinações do ouvido não são só as mais frequentes, são muitas vezes quase as únicas, pelo menos muito distanciadas da evolução da doença daquelas outras que podem surgir em época remota, como produto da deterioração mental. O nosso colega, Dr. Manoel Bonfim, num ensaio sobre o assunto, e que teve a fidalguia de nos comunicar, parece ter atinado com motivo dessa primitividade, senão singularidade, de alucinações de ouvido na paranoia. A alucinação de ouvido seria no paranoico o seu pensamento ouvido, após a ruminação contínua e automática das mesmas ideias de defesa da personalidade agredida; e como lhe falta a consciência dessa elaboração mental, a associação de atividades integradoras dos centros que presidem a elaboração da palavra falada e dos que são o sensório-auditivo faz que eles atribuam a uns o que só existiu nos outros. É convincente, e parece destinada a fazer carreira, tal interpretação psicológica.

Só muito mais tarde é que, tomados inteiramente todos os centros sensoriais, as outras espécies de alucinações sobrevêm; raras, ainda assim, as da vista, mais comuns as da sensibilidade geral, atormentada então por contas, cáusticos, venenos, etc.

Os falsos reconhecimentos são muito comuns e, não raro, no presente e retrogradamente, acusam ter visto tais e tais pessoas em tais e tais situações, o que permite e facilita sua eterna ruminação. Dois dos nossos paranoicos vêem ou julgam reconhecer em senhoras que transitam nos tramways suas prediletas, que passam, para escarnecê-los, talvez.

As interpretações falsas não são de estranhar, descritas que foram a estrutura e função do Eu paranoico desequilibrado: formam amiúde e têm como fundamento as mais disparatadas ocorrências. Um olhar, um gesto, uma mão que se deixou de apertar, um sobrolho carregado, uma palavra distraída, ou extraída do meio de uma frase, etc., bastam para o núcleo de uma interpretação falsa, coerente com a tendência pessoal de cada paranoico. Um dos nossos doentes, o A., catou os seus inimigos no almanaque Laemmert, por induções, ilações, combinações, que ele mesmo não consegue bem explicar: um pouco mais tarde, pelo mesmo processo, inocentou ao primeiro acusado, e arranjou no indicador mencionado em outro nome, que, por motivos especiosíssimos, é do seu atual cabrion.

As funções psíquicas, malgrado a labuta contínua do cérebro paranoico, numa perene cogitação de fato, e num contínuo abalo de emoções desagradáveis, resistem muito tempo e muito bem; abstração feita das falsificações da memória, das interpretações, sempre orientadas no sentido de seu delírio, o paranoico conserva esses mesmos territórios psíquicos válidos para todas as outras ocorrências. A demência é um fenômeno raro e demorado nestes casos: quando muito se vai notando, de longe em longe, uma deficiência se ir esboçando.

A conduta do paranoico deverá ser sempre coerente com o seu delírio: é um fato que se não verifica sempre, felizmente. Se uns se incompatibilizam com o meio pelas ameaças, tentativas e até feitos criminosos, muitos outros não passam das primeiras e, ainda assim, apesar de suas afirmações fanfarronas, são suscetíveis de intimidação. $\mathrm{O}$ dito popular nunca veio a talho de foice, como para estas situações: má-criação não é valentia. 
Vimos muitas vezes alguns recriminantes, ameaçadores, se abrandarem com uma palavra, propositalmente áspera, com uma delicada interpelação e uma admoestação formal. Como quer que seja, porém são doentes insuportáveis: a paciência se gasta em aturá-los em suas eternas queixas, recriminações, exigências, protestos, ameaças... São muitos deles o tormento de jornalistas a quem reclamam, da polícia de quem se queixam, dos tribunais para quem apelam, dos médicos a quem ameaçam... Escrevem cartas, exposições, artigos, requerimentos, pedidos de habeas corpus, memórias e até obras tendentes a demonstrar sua sanidade mental ou seus direitos violados. Dois dos nossos doentes dirigem vários pedidos de habeas corpus ao Supremo Tribunal Federal e, um destes, fundamentado em grosso volume contendo versos, obras da matemática, discussões sobre o divórcio, legislação, em latim, do concílio de Trento, sobre o sacramento conjugal, para provar a sua razão sã e a ilegalidade da reclusão.

\section{Diagnóstico}

O diagnóstico diferencial da paranoia, assim compreendida pelo recorte nítido que lhe traçamos, é facílimo e basta apelar para suas qualidades essenciais para afastar todas as outras enfermidades do espírito, em que as delusões existem.

Primitiva e originária autofilia que a educação permitiu e favoreceu: inadaptabilidade do Eu desmedido ao meio não conformado: ação e reação persecutórias; sistematização de ideias e consecutivamente de delírios, coerentes, lógicos, fixos, possíveis, com retrospectiva falsificação da memória, chegando até a mudança de personalidade; raridade das alucinações e precocidade das auditivas sobre as outras; com uma inteligência lúcida e resistente por longo tempo sem deteriorações demenciais, - aí está com que se separar a paranoia destes epifenômenos que surgem de irregular e despropositadamente, sem fundamento nem coesão, com arcabouço evidentemente alucinatório, pelos múltiplos e profundos erros sensoriais, que chamamos síndromes paranoides, comuns a todas as doenças mentais.

Bem se vê que uma relação deve de exigir entre essa paranoia organizada e íntegra e esses trechos paranoicos, sim, tanto quanto em semiologia é a relação entre as síndromes inconstantes ou incaracterísticas que surgem em várias doenças e aquelas outras que se afeiçoam por essa constante manifestação.

A gênese da ideia paranoica e paranoide é a mesma; autorreflexiva; é a personalidade que inconscientemente refere a si mesmo suas sensações internas ou externas e automaticamente as remói, sem o corretivo da consciência, num critério pejorativo ou expansivo. Apenas, estes fenômenos, que têm raízes na psicologia normal, se apresentam com um desenvolvimento integral, evolutivamente crescente, organizado em sistema, enquanto, por longo tempo, é lúcida a inteligência - na paranoia; mais ou menos frustros, abreviados, sem coesão sintomática, com um cunho de absurdidade manifesta, permitida pelas profundas lesões da consciência - nas psicoses agudas, nos episódios dos degenerados, nas deteriorações demenciais. Processo agudo, pois que gera a confusão, a incoerência, o absurdo nas intoxicações, autointoxicações, infecções, paroxismos episódicos ou processos crônicos, que produzem a inconsistência, a incoerência, o absurdo nas dissoluções da inteligência: jamais se confundirão com a paranoia, anomalia que se transforma longamente em doença e em que a consciência perfeita e a inteligência respeitada separam todas as confusões possíveis. Estender o nome paranoia àqueles estados é abusivamente 
misturar na mesma designação fatos que se não parecem sob nenhum critério, dos aceitos em patologia, para a individuação nosológica. Seria fazer apenas semiologia e nunca descer mais fundo na difícil interpretação das causas e conhecimento da evolução.

O dilema existe: ou a paranoia é a doença mental que descrevemos e paranoides apenas são as síndromes que acorrem em tantas outras doenças mentais, ou esse termo serve a estes estados, e então, força é buscar um outro que designe aquela doença. O que se impõe à inteligência clínica, como produto da observação, é que não são a mesma coisa e portanto, para nos entendermos, não devem ter o mesmo apelido.

Nos primeiros e superficiais exames certas formas de demência precoce, as paranoides, poderiam dificultar a diagnose diferencial. A multiplicidade de alucinações, a incoerência e a absurdeza do delírio e os indícios bem notáveis de enfraquecimento mental traçam quase sempre, ou em breve espaço, uma separação bem clara. Convém dizer entretanto que nos casos chamados em psiquiatria francesa de delírio crônico, em que por vezes a demência tarda, e o mesmo outros em que ela parece já se ter instalado - a demência, na chamada demência precoce, é de certo modo relativa, e mais de uma feita se encontram em territórios mentais, se não poupados ao menos mais resistentes às causas da deterioração; entretanto a observação de todas as funções psíquicas dá o início desta acentuada miopragia cerebral.

Sobre o assunto, tão claro se nos afigura ele, depois que o gênio de Kraepelin o iluminou, expungindo-lhe as sombras, que não fazemos dúvida: melhor que estas palavras alguns fatos dirão. As observações seguintes, buscadas sem propósito, apresentam espécies mórbidas que tínhamos à disposição, em que como epifenômenos existem síndromes paranoides. Como este trabalho tem alcance apenas didático, não pretendemos abusar dos exemplos, e é por isso que são singulares para cada espécie psiquiátrica. A delimitação entre a paranoia e os sintomas paranoides fica por eles nitidamente traçada.

\section{Observações}

\section{Paranoia}

G.P.O., 43 anos, branco, casado, bacharel em ciências físicas e naturais. Na sua família encontram-se como dominantes a tuberculose e a nevropatia. Tuberculosos: o pai, um tio e uma tia paternos, uma tia materna, casada com esse tio, uma irmã que também sofre da espinha dorsal (mal de Pott?), dois primos germanos, filhos de um tio paterno, ainda são. Nevropatas: a mãe, duas irmãs (uma sofre de talassofobia) e uma tia, histéricas; uma prima idiota e um primo demente precoce. Existem igualmente muitas pessoas sãs e outras de inteligência elevada, que exerceram e exercem função social distinta: o pai e um tio foram brilhantes professores da Escola Politécnica, sendo este autor de várias obras escritas e trabalhos profissionais de merecimento, um primo e um tio são médicos de importância; outro tio, oficial de marinha, morreu em combate na Guerra do Paraguai. Um primo é criminoso, sedutor uma vez, assassino outra; pretendeu o pai, tio do doente, provar ser ele um louco: escrevia protestando contra esta alegação, defendendo-se com a afirmativa de nunca ter praticado crime algum. Outro fato é de notar-se: há na família uma atmosfera de religiosidade e misticismo: fervor católico extremo nas mulheres e tendências públicas positivistas em alguns homens. 
Foi desde o começo da sua vida considerado muito inteligente: aos quatro anos de idade recitou versos de cor, à chegada do pai, que regressava da Europa. Pouco depois este lhe faltou, ficando sua educação a cargo da avó e da mãe que o cumulavam de vontades. Aos 9 anos uma pneumonia dupla. Fizeram-no extremadamente religioso: ia às missas, confessava e comungava semanalmente. Cuidavam-no com um desvelo excessivo: avó, tias, mãe, irmãs serviam-no com solicitude e progressivamente com submissão: a sua vaidade e o seu egoísmo prodigiosamente cresceram neste ambiente. Na própria família, geralmente, se atribui a esta causa a sua doença atual: apenas uma acentuação do longo e sucessivo preparo que veio tendo. Quando entrou para a Escola Politécnica considerava-se já um talento e se ufanava amiúde de neto do conselheiro F., filho do Dr. S. etc. Sempre foi pesadíssimo aos seus; deixava-se servir, nunca lhes medindo forças, nem se incomodando com os sacrifícios que exigia e não lhe retribuindo com o mínimo auxílio. Aos 19 anos, sem meios de vida, era noivo e exigia dinheiro das tias para dar presentes à noiva. Apenas formado, aos 22 anos, tratou de casar. A família subvencionou tudo e lhe arranjou uma colocação. Ainda depois de casado, como sempre, as tias lhe forneciam dinheiro.

Já de algum tempo usava de alcoólicos, chegando a beber águas de toilette; tornava-se então agressivo e ofendia a esposa. Teve dois filhos, mortos de varíola, não os tendo vacinado por ser contrário a essa profilaxia a seita positivista a que se filiara, depois do ultramontanismo dos primeiros anos. A mulher por fim abandonou-o, fugindo com um oficial de marinha. Teve diversas colocações como engenheiro, em estradas de ferro em Minas e no Estado de Rio; pouco persistia nelas, por incompatibilidade de humor e insociabilidade de seu caráter vaidoso e egoísta. Em Macaé, atacado de impaludismo, foi servido, na casa em que se hospedara, por uma criança de 11 anos, Januária, que lhe dava os remédios. Quando pôde voltar a Niterói levou consigo a menina, por oito dias, e como, passado estes, não a mandasse, veio o pai buscá-la. Algum tempo depois voltava ele a Macaé, insistindo com o pai de Januária, para que lha desse, para educar. $\mathrm{O}$ paludismo voltou, teve repetidos acessos e nestas ocasiões episódios delirantes com síndromes paranoides de perseguição, agarrando-se, transido de medo, aos braços das tias que o iam visitar, dizendo que o queriam matar. Com o tratamento, numa casa de saúde, ficou bom, tendo alta pouco depois. A preocupação pela tal menina não passara entretanto. O seu interesse já era então o de um violento amor carnal: cercava-lhe o retrato de flores, fazia-lhe versos, referia-se impudentemente a ela e quando repreendido pela família, exasperava-se. Consultou vários sacerdotes, desejoso de se casar, e como lhe dissessem que tal não poderia porque era casado e o vínculo persistia, injuriava-os, discutia a questão canônica e a questão jurídica, com abundância de argumentos. De então pra cá vive a ler e escrever sobre o divórcio e progressivamente veio a se supor, a se crer firmemente divorciado.

Um tio dirigindo os Telégrafos obteve-lhe uma boa situação neste departamento de serviço público: pouco durou isto. Escarnecia-o e o insultava, passando os dias a lhe lavrar a demissão da diretoria de Telégrafos. Na sua ausência, um dia, armado de revólver, sentou-se na mesa do diretor, declarando ser o único homem capaz de dirigir a repartição. Sabido o fato foi imediatamente demitido. Desde então esse tio transformou-se no objeto de seu ódio: diz dele as maiores infâmias e chama de perseguição a que sofreu, quando "devia esperar a recompensa do que seu pai fez a esse irmão". Não ficou aí, começou a dar sucessivos escândalos à porta das tias já então privadas dos pequenos pecúlios que tinham, porque os gastaram com ele: estas pobres 
senhoras, habitando uma casa pia de educação, foram ameaçadas de despejo. Foi então que se concertou entre os parentes interná-lo neste Hospício.

É um homem bem conformado, sem estigmas físicos de degeneração, de aparência correta. Revela alguma cultura literária e científica e tem um entendimento perfeitamente lúcido. Refere a sua história a seu jeito e com desconfiança, votando um ódio de morte ao tio, ao qual mimoseia com os qualificativos mais abjetos. Atribui as perseguições do tio e seu internamento no Hospício ao fato de ter o mesmo parente práticas obscenas com a Janú, como chama a apaixonada: repousa esta afirmativa em fatos especiosíssimos por ele interpretados.

Vive a escrever cartas a todos os funcionários da Nação, advogados de nome, personagens notórias, patentes elevadas do exército, seus parentes etc., queixando das torpezas a que o condenam e exigindo em nome da lei a sua liberdade; quer mais uma indenização e restituição de seus empregos. Quer a todo o transe esposar a Januária; fala dela com o erotismo mais apaixonado, e não raro com uma lascívia requintada. Nunca escreve a uma só pessoa; muitas cartas que faça, são sempre, cada uma delas, dirigidas a duas, três diferentes. Tem alucinações auditivas: ouve chamarem-no "irmão franciscano, Francisco, já estás na ordem, já estás no adro", alusões aos seus amigos da Igreja. Supõe-se perseguido pelos salesianos, franciscanos, religiosos em geral, porque estes não admitem o seu segundo casamento, pela Igreja; pelos positivistas porque são formalmente antidivorcistas; pela maçonaria "porque acha que ele se deve contentar com qualquer mulher e não especificadamente com uma”. Durante o dia escreve e faz mil ações opostas: pede e recusa, escreve e rasga, apela e desconfia, numa variação constante: só não muda a sua ideia, fixa cada vez mais: a Janú... quando não é esta a preocupação do momento, nem são as queixas das alucinações interpretadas a seu saber, é calmo, lúcido, conversando perfeitamente bem o escrevendo tratados, versos, comentários, reformas, etc. Pela marcha da doença, até agora, a deterioração mental virá recuada.

\section{Neurastenia constitucional e síndromes paranoides (perseguição, negação, enormidade)}

J.D.R.C. 35 anos, branco, brasileiro, casado, advogado e funcionário público. Pais mortos: pai de hepatite, mãe cancerosa, irmã histérica. $O$ doente não teve moléstias graves anteriores, era morigerado, não dado a excessos, exercendo seu cargo administrativo com exacção. Casado, durante os três primeiros anos, vivia alegre, folgazão, gostando de festas e sem motivo de contrariedade. Depois, há dois anos, começou a sentir-se enfraquecido, exausto, queixoso ou irritadiço, impressionado; o menor exercício fatigava-o, suava abundantemente e à noite era preso de insônias. Perturbações digestivas. Cefalalgias. Emotividade às vezes fácil, chorava por circunstâncias mínimas. Cumpria contudo os seus deveres, conversava e procedia bem. A irritabilidade em certos momentos era explosiva, exacerbava-se, gritava e pedia um remédio para acalmar; isto durava pouco e em breve estava quieto e sossegado. O estado de depressão psíquica foi-se acentuando, o menor trabalho mental fatigava-o em excesso. Uns vinte dias antes da primeira grande crise começou a se impressionar com ladrões, tendo o receio de ser roubado. Em 4 de Março, à noite, começou a gritar, pedindo socorro; quinze minutos depois estava serenado. No dia seguinte pela manhã teve outra crise mais duradoura, falando e gritando aterrorizado; os acessos passaram, mas, se repetiram após três meses. Cederam depois, sendo substituídos por simples excitações em que se capitula de um ser inútil e em putrefação. 
Apresenta estigmas de degeneração (estrabismo, viciosa implantação dos dentes), reflexos exagerados, língua saburrosa e trêmula, distúrbios digestivos, ptialismo constante, mau hálito, constipação de ventre, dores de cabeça, dores erráticas; fisionomia contraída e dolorosa, retardamento dos processos psíquicos e elementares, percepção defeituosa; distraído e abstrato o doente parece não compreender o que se indaga ou responde custosamente. Insônias tenazes. Perturbações cinestésicas. Alucinações visuais e motoras, delírio de perseguição: aparece-lhe um preto, no quarto, que o provoca e com quem entra em luta, ficando deste violento exercício exausto e sucumbido durante horas. Nos espaços intercalares fica muito apreensivo e amedrontado com semelhante agressão. Queixa-se de dores de cabeça, dores em todas as partes, não podendo às vezes localizar onde; tem se queixado de que lhe faltam braços, pernas, conclui que está em putrefação. Em outras ocasiões parece-lhe que a cabeça toma proporções extraordinárias. Urina-se sempre que entra em luta com o preto imaginário.

O regime do leito, dieta alimentar, tônicos, hipnagogos, melhoram este estado; saiu para ser tratado em família a nosso conselho.

\section{Epilepsia e síndromes paranoides (perseguição e autoacusações)}

A.M.C., 32 anos, branco, português casado, trabalhador. Os pais estão vivos e residem nos Estados Unidos. Tem dois irmãos sadios. $\mathrm{O}$ doente diz ter tido duas vezes a febre amarela no Brasil; acidentes venéreos. Abusa de bebidas alcoólicas. Sofre de ataques epiléticos, não sabe dizer desde quando, precedidos de auras e seguidos de amnésia; além disto, impulsos e delírios de ação agressiva e inconsciente, acompanhado de alucinações visuais e auditivas, delírio persecutório; sonhos e pesadelos frequentes; delírio onírico. Estigmas físicos de degeneração, cicatrizes na língua, tremor fibrilar dos dedos; reflexos normais. Tem um dos dedos enormemente inflamado e ferido por dentada de outro alienado com quem entrou em luta numa de suas crises. Extremamente suscetível e irritável; à menor pergunta que se lhe dirija julga-se magoado e ludibriado, responde mal e de modo agressivo. À custo, de testa franzida, rosto congesto, olhos brilhantes, referiu, que estando dormindo, foi assaltado por um sonho horroroso no qual viu morta sua mãe. Sobressaltado despertou em grande excitação nervosa, seguindo-se pranto copioso. Interpelado pela mulher contou-lhe o fato como uma realidade, deplorando não lhe ser concedido o consolo de assistir os últimos momentos. Não foi possível demovê-lo desta ideia falsa durante o resto da noite e dia seguinte, quando se dirigiu para contar o fato a um padrinho. Este não logrou convencê-lo de sua suposição infundada, ficando o doente cada vez mais certo de que era verdade. A ideia falsa tornou-se ideia fixa, não o deixou mais, e o doente começou a atribuir-se esse castigo pelo fato de deitar água no leite que então expunha à venda. Por esta ocasião sobrevieram alucinações visuais e auditivas intensas, delírio de perseguição, impulsos tão violentos que o levaram a atirar-se contra sua madrinha e diversas outras pessoas que junto dele se achavam, chegando mesmo a ofender fisicamente àquela senhora. Quebrou móveis, vidros, pratos que encontrou à mão, sendo preso por dois guardas que acudiram de perto. Na prisão e no Hospício, para onde o conduziram, o seu delírio tocou ao auge do furor, promovendo desordens, atacando os outros alienados, sendo, em defesa contra suas agressões, mordido num dedo por um deles. Estas crises são inconscientes, restando completa amnésia delas e às vezes dismnésia retrógrada.

Submetido a tratamento, melhorou, saindo a pedido da família. 


\section{Degeneração inferior e síndromes paranoides (perseguição, grandeza, misticismo)}

E.R.C., 22 anos, pardo, brasileiro, solteiro, sem profissão. Pai alcoolista. Mãe e irmão sadios. Em criança deu uma queda da qual resultou uma luxação coxofemoral, com ancilose, encurtamento e atrofia do membro inferior direito. Estigmatização degenerativa: orelhas mal orladas, tubérculo de Darwin à direita, lóbulo aderente; órgãos sexuais pouco desenvolvidos, nunca exerceu o coito. No membro inferior direito atrofiado e encurtado de 10 centímetros apresenta os reflexos aquilianos e patelar exaltados. Pequeno desenvolvimento mental; memória, atenção, percepção regulares.

Confessa ter abusado de alcoólicos, embriagando-se várias vezes, cessando de fazê-lo depois que Nossa Senhora, sua mãe Maria, ordenou-lhe de salvar o mundo. Refere ser de condição humilde, filho de trabalhador e de uma lavadeira; tinha agasalho numa casa onde se ocupava em lavar o assoalho. Depois que a Virgem lhe apareceu, o rei Roberto dos Infernos andou atrás dele experimentando-o, se era ladrão ou assassino ou se tinha bom coração; depois os jesuítas vieram em sombra com guarda-chuvas e cacetes, perseguindo-o, por ser ele o preferido de Nossa Senhora. O seu pai do Céu apareceu-lhe então dizendo que os jesuítas estavam presos, falou-lhe em turco, linguagem que foi traduzida pelo seu anjo da guarda; preveniu-lhe mais que seria preso pela maçonaria. Com efeito foi conduzido à prisão e depois a este Hospício por um guarda noturno e soldado de polícia. Perfeitamente orientado quanto ao tempo e ao meio, supõe que seu destino depende da Maçonaria e espera. Humor variado: ora tranquilo, satisfeito, eufórico, ora agitado, claudicando, reclamando a saída. "Precisa de sua liberdade, precisa salvar a Nação e libertar a imagem de Cecy (personagem de um romance nacional) que está guardada na bandeira". "Não é rico, porque de dinheiro não precisa; se não o tem, tem as palavras; dentro de uma prisão salvase a si mesmo; só precisa de uma roupa de algodão e salvar todas as nações, porque é brasileiro". É patriota, canta: "a Europa curvou-se ante Brasil..." aludindo à conhecida trova popular em honra de Santos Dumont; "salvou o mundo porque fugiu dos jesuítas..." . Em algumas ocasiões fala em cassange, com los, las, interpolados, e supõe língua francesa.

\section{Psicose tóxica (alcoolismo) e síndromes paranoides \\ (grandeza, perseguição e delírio de ciúme)}

I.M., 43 anos, branco, brasileiro, casado, jornaleiro. O pai morreu paralítico, hemiplégico, pela descrição; a mãe era sujeita à ataques em que ficava rija, resfriada, inerme. O paciente teve sífilis, de que ainda apresenta vestígios: dores ósseas, cicatrizes cobreadas, etc. Abusa inveteradamente do álcool, sob todas as suas formas, tendo frequente embriaguezes e acessos maníacos por essas ocasiões. Esteve já neste Hospício por este motivo. Estigmas físicos de degeneração, face assimétrica, orelhas de lóbulo incluso; língua com saburra espessa, trêmula, tremor fibrilar e da mão estendida; reflexos abolidos; face congesta, báquica; memória, atenção regulares, percepção difícil, voz éraillée; loquaz, eufórico, movimentado. Diz que veio ter aqui chamado pelo Sr. M., diretor do Hospício (dá o nome de um dos enfermeiros) pois tem 300 contos emprestados à casa, outros 300 emprestou-os ao correio, comprou casas, fez negócios, é poderoso e rico. Confessa entretanto que vivia pobremente, ganhava $180 \$$ mensais como estafeta do correio, conduzindo malas. A sogra é a sua inimiga irreconciliável, persegue-o ferozmente, é 
um verdadeiro dragão, procurando indispô-lo com a mulher e tendo até obrigado a usar de beberagens, suor de cavalos, etc., sob pretexto de curá-lo do vício da embriaguez. A mulher no começo estimava-o, mas agora vivia em conversas até tarde com um carroceiro; está certo, no momento, de que o fraudava. Fala em tigres, onças, bichos ferozes que matou em caçadas na costa da África (onde nunca esteve) de parceria com o Venancio; muitos destes animais estão agora no seu corpo, caminhando nas suas veias, donde os procura tirar com pregos e alfinetes.

A eliminação do tóxico e dos autovenenos consecutivos foi delindo esses conceitos delirantes.

\section{Psicose autotóxica (por obesidade, dismenorreia) e síndrome paranoide (perseguição)}

C.M., 39 anos, mestiça clara, filha de português e neta de africana; da Bahia. Mãe e avó polisárcicas, tia vesânica na velhice. Crescimento muito precoce; aos 11 anos era púbere, regrada e enormemente desenvolvida; apesar disto, uma cloroanemia moveu a retirada do colégio. Casada aos 22 anos; dismenorreia, frigidez sexual, esterilidade. Embora o estado anêmico a acentuação da polisarcia foi ativa e laboriosa, intervindo em todos os negócios do marido. Os mênstruos falhavam anos inteiros, só aparecendo às vezes por provocação médica; suspeita de intervir para isto uma atresia do colo do útero foi o mesmo dilatado; as regras vieram para cessarem pouco depois. Atingiu a obesidade, pesando 119 quilogramas. O marido, homem de negócios, andava envolvido em empresas cuja sorte dependeu do governo, com quem se entendia pelo intermédio da amante de um ministro; a ação foi demorada e por esse tempo (há cinco anos) começou a paciente a atribuir perturbações cenestésicas à influência da outra, que nem conhecia de vista, mas supõe querer matá-la para casar com o marido, que é rico, usando para isso todo gênero de perseguições, insultos, obscenidades, infâmias que ela ouve, atitudes decompostas, atos licenciosos e pudendos que ela $v \hat{e}$, choques elétricos terríveis que ela sente e que lhe são prevenidos pela inimiga que lhe diz estou apertando, estou apertando. Alucinações e obsessões constantes há quatro anos, tem acuidade, porém, no período pré-menstrual, quando é assaltada por dores de cabeça e no fim do catamênio, sempre escasso e irregular. Conseguiu melhorar um pouco com o tratamento da obesidade na Europa: exercícios, caminhadas a pé, regime estrito, cura hidromineral fizeram diminuir 17 quilogramas e passar quase as ideias e delírios persecutórios. Voltando ao Brasil e aos antigos hábitos de inércia, sem regime alimentar conveniente, os males se acentuaram agudamente. A inimiga está implacável, persegue-a obsedantemente. Nenhum procedimento do marido justifica absolutamente esta ideia fixa: é muito carinhoso, dedicado, e vivem aliás em perfeita harmonia conjugal. Por duas vezes já ela se dirigiu ao Palácio do Presidente da República para invocar o auxílio do governo contra a perseguição que sofre. Quer que o marido adquira uma poderosa máquina elétrica para se vingar e dar na outra uns choques violentos. Esta ideia de vingança consola-a.

A atitude perante estranhos é calma, serena e risonha, às vezes; foge da conveniência, isola-se e se entrega às suas ideias: apenas ao consorte e às autoridades confia suas penas. Processos psíquicos tardos, memória dos fatos recentes alterada. Estado geral sem aparente perturbação, apenas a obesidade cresce e com ela o delírio paranoide. 
Psicose infecciosa (malária) e síndromes paranoides (culpabilidade, autoacusação), uncinariose

J.C., 35 anos, branco, espanhol, solteiro, lavrador. Antecedentes hereditários omissos. Teve acidentes venéreos e febre amarela ao chegar ao Brasil, há 11 anos, e desde 1893 é cometido de sezões que nunca o abandonaram, pois reside desde esse tempo em focos de endemia malárida (Parati Guaratiba); nunca usou o tratamento específico. Foi sucessivamente se enfraquecendo e descorando, até recentemente, em que teve acessos de febre muito violentos e por essa ocasião começou a cismar que um vizinho que supõe sem motivo plausível, não gostar dele e lhe ser hostil; estas cismas preocupavam-no muito e durante algum tempo ruminava o motivo dessa indisposição: atentou porém que talvez o fato fosse devido a se chamar José Casado, quando de fato era apenas amasiado com sua mulher; de permeio surgiram ideias de que era um pecado, certamente punível pelos Santos. Resolveram um dia pôr termo a estas aflições casando-se; no lugar não havia padre, fez um altar, colocou sobre ele a imagem de Nossa Senhora do Rosário, chamou a mulher, juntou a sua e a mão dela, pronunciou as palavras do Sacramento, dando-o como realizado. Mal acabada a cena, apossou-o imediatamente a ideia de que tinha cometido um sacrilégio, estava agora mais digno de punição: agarrou-se chorando e gritando à efígie da santa. Intervieram pessoas para acalmá-lo e, cuidando perseguidores, correu espavorido para o campo gritando, abraçado à imagem; tropeçou, caiu e o lenho representativo da santa partiu-se em pedaços. Agora sim, estava irremediavelmente perdido, crime sobre crime... e numa agitação furiosa, chorando e vociferando a um tempo, querendo fugir e morrer, foi alcançado, preso e metido em camisa de força. Fizeram-no transportar para o Rio, entregue à polícia. Nesta noite teve um acesso violento de febre e foi preso de um delírio intenso, povoado de alucinações terrificantes, soldados, demônios, perseguindo-o e ameaçando. Assim entrou para o Hospício.

É um homem bem conformado, não apresenta estigmas de degeneração. Mucosas descoradas inteiramente, pele amarela exangue: fígado e braços hipertrofiados, edema maleolar e palpebral; acessos febris tipo terção. Foram encontrados no sangue hematozoários, formas em crescentes, corpos esféricos e em rosácea. Por ocasião da invasão do acesso, o doente insistia em suas ideias de culpabilidade e perseguição passiva. Tratamento específico incisivo (2 gramas de cloridrato de quinina pro die, em injeções intramusculares retro trocanteriano). Os acessos passaram, e o delírio com ele. Restaram a mesma palidez, edemas, e uma depressão acentuada do humor: o doente chora amiúde e diz que lhe parece "tudo o que faz, malfeito, é uma coisa ruim, não presta mais para nada”. Exame de sangue 1.000.000 de hemácias e 9000 leucócitos por m.m.c.; $2 \mathrm{gr}$ de hemoglobina para 1009c.c. ou 12,5\% no hemômetro de Fleisch-Mischer. Exame das fezes: óvulos de uncinária em abundância; Thymol em doses de 12 gramas pro die por três vezes, e feto macho por se ter verificado a persistência de óvulos dois dias depois de cada medicação. Desaparecimento de óvulos e vermes adultos; ferruginosos. O doente curado embora ainda pálido, retirou-se para convalescer no campo. Nenhuma alteração psíquica existia mais um mês antes da alta.

\section{Loucura maníaco-depressiva (predominância maníaca) e síndromes paranoides}

T.M.F., 35 anos, branco, brasileiro, casado, militar. Tara pesadíssima; avô materno, pai, mãe duas tias maternas, irmãos, filhos eivados. Avô materno maníaco, querelante inveterado, 
comprando questões no foro, perdendo nisto parte da fortuna. Pai usava intemperadamente de alcoólicos, erótico, sifilítico. Mãe histérica, vesânica: após a morte do marido capacitou-se que ao casar o último filho (o paciente) viria el-rei D. Sebastião casar-se com ela; esperava o fato e mesmo dizia só faltar casar positivo, pois já tinha feito negativo, isto é, já tinha relações com os poderes dele e mais uma vez se apresentou grávida, dizendo-se com dores de parto, dessa origem. Quando o filho mais moço se casou, não tendo aparecido o encantado rei, caiu em profunda depressão melancólica, falecendo a breve trecho. Uma tia (irmã gêmea da mãe do paciente) é delirante crônica paranoide sujeita a impulsos: tem filhos, alguns de inteligência brilhante, mas todos desequilibrados, ticosos, nevropatas. A outra tia já duas vezes enlouqueceu. Irmão genioso, irritável, neurastênico. Onze filhos: cinco abortados, seis viáveis; destes já três mortos precocemente em convulsões e meningite. Nasceu de parto operoso. Onanista, pederasta em menino; sujeito a assombramentos; terrores noturnos, pesadelos. Hérnia umbilical. Hapatite supurada (foi operado). Casou-se aos 29 anos com uma histérica de 14, também erótica e fortemente tarada; além de ser homem constituído e válido, auxiliava-se com as cantáridas. Pai extremoso. A morte dos filhos, a começar do primeiro, foi sucessivamente abalando sua mal assente saúde mental. Morto o primeiro, entrou a excitar-se, delirando em grande agitação. A calma se seguiu em depressão acentuada. Um mês depois segundo filho adoece e morre: mesma excitação, delírios e ideias de ressuscitar os dois, estudando os meios, cogitando possibilidades. Nova depressão e calma consecutiva. Seguindo um ano para Mato Grosso, terceiro filho adoece gravemente: por ocasião da morte deste, loquaz, agitado, falava em ressuscitá-lo com um invento seu, um elixir de longa vida, pela conservação do calor, depois cantou, chorou, dançou, atacou transeuntes, quebrou móveis, deu dentadas, sendo metido em camisa de força.

É um homem forte, bem constituído, sem estigmas físicos de degeneração, embora a tarra carregadíssima; nos momentos de calma é correto, palavroso, alegre, espirituoso; respostas claras, coerentes, nenhuma confusão de espírito, sempre lúcido. Móvel: agora palavroso, alegre, pornolálico, cantando obscenidades, adiante descrevendo seus inventos, planos, teorias, depois vociferando, descompondo, gesticulante, ameaçando, mais tarde emotivo, choroso, ajoelhado, mãos postas implorando graças para seus filhos, vaidoso da mulher. Crises de excitação maníaca e depressão melancólica bem diferenciadas. Ao entrar referiu ter descoberto grandes coisas e fatos, máquinas, elixir de longa vida (fundado na conservação o calor, na coesão, na afinidade, na gravidade, na boa vontade, na teoria das massas vivas de Newton), movimento contínuo, teoria das coincidências, etc. Nestas ocasiões quem não o visse antes, nem o veja depois, suporá um delirante crônico ou um paranoico. O próprio doente qualifica estas concepções de polimania. É a desordem da secção: tudo o interessa, em tudo intervém: na visita médica, no receituário, no tratamento dos outros. Nos seus momentos de excitação faz todos os atos imagináveis de extravagância: tem saltado janelas, quebrado móveis, rasgado a roupa, triturado com os dentes pedaços de mármore; pinta-se com os ovos da refeição ou se empoa com o cloreto de cálcio que encontra nas latrinas. Saiu, três vezes depois do primeiro acesso, em estado de completa remissão para 15 dias depois ser acometido de outro mais violento, ainda em cujo tratamento se acha. 


\section{Loucura maníaco-depressiva (predominância melancólica) e síndromes paranoides (perseguição, culpabilidade)}

B.L., 27 anos, pardo, brasileiro, casado, negociante. Antecedentes hereditários exíguos e negativos. Franzino, linfático, imberbe, não apresenta estigmas de degeneração, não tem moléstias graves anteriores. Tímido, delicado, regular, sem hábitos viciosos, amando extremamente a esposa. De há algum tempo o seu espírito se combalia por desgostos domésticos reiterados: a mulher embriagava-se e armava escândalos com os criados e até com os vizinhos. Um dia, ao entrar em casa, informa-lhe a esposa que havia sido gravemente injuriada por uma mulher de má vida, aflige-se demasiado, procura a autoridade policial, exigindo que fosse a cabeça raspada à ofensora; não podendo ser atendido, desistiu da queixa, à noite ouviu vozes insultuosas, gritos ofensivos a si dirigidos, não podendo dormir. Começou daí a ouvir palavras estranhas, agressivas, vendo indivíduos desconhecidos e outros já mortos, exigindo alimentos das casas vizinhas, temendo envenenamento. Nestas ocasiões, triste, abatido, tomado de pânico, procurava refúgio na rua e nas companhias amigas, verdadeiro monófobo. Estas crises se intervalam com outras de delírio religioso em que, ajoelhado, em postura contrita, olhos voltados em êxtase para o alto ou humildemente dirigidos ao chão, balbuciando preces, persignando-se, etc., julgava sua casa um templo "onde ninguém devia cuspir para não profanar o santuário"; adorava duas oleografias da parede e uma mandolina, considerando-as efígies e imagens divinas. Cessados esses delírios subsistiam a depressão, o abatimento, o sofrimento moral, fundo constante do quadro: braços pendentes, olhos baixos, expressão dizimada, silencioso, quase inibido. Depois novas crises de agitação, pânico, terrores, perseguições passivas, receio de envenenamento. Tentou por duas vezes suicidar-se para escapar às suas misérias.

O doente apresentou-se abatido, descarnado, com bradicardia, hipopneia acentuadas, pulso lento e depressível, pele resfriada, movimentos demorados e preguiçosos. Anorexia intensa, sitiofobia, receando venenos nos alimentos, digestões difíceis, constipação de ventre; insônias e sonos interrompidos por concepções terrificantes. Queixa de angústia precordial e sensação de secura na fronte. Embaraço dos processos psíquicos: percepções diminuídas, memória fraca, vontade abolida, energia extrema, anestesia psíquica completa (a mulher lhe é absolutamente indiferente, os seus negócios não lhe merecem a mínima preocupação). Os mesmos estados de depressão melancólica, com ideias hipocondríacas, místico e extático. Remissões ordinariamente à tarde chegando o doente a entrever a inanidade de suas concepções, declarando "nada a dever nem temer por não ter inimigos". Não se lembra de pecados e crimes, "mas a gente os tem às vezes sem saber". Alucinações psíquicas (Baillarger) inversas (Peixoto): o doente confessa que às vezes the vem a vontade de dizer palavras insultuosas às pessoas presentes: então, se não se pode conter, elas se escapam pela boca, se consegue evitar, saem pela cabeça. Supõe percebidas estas injúrias pelas pessoas a quem mentalmente elas se dirigem, tanto que lhes pede perdão depois, são palavras sem som, vozes interiores sem ruído, produzindo efeito externo: locução intelectual, comunicação de alma a alma que se dá, não do exterior para o interior (alucinações psíquicas de Baillarger), mas do interior para o exterior, inversas, portanto.

Teve uma remissão completa após isolamento nosocomial de alguns meses; voltando são à casa: a observação de idênticos cenários, como antes do primeiro acesso, determinam um segundo, que perdura. 


\section{Melancolia de involução \\ e síndromes paranoides (perseguição e culpabilidade)}

J.F.S., 57 anos, branco, português, viúvo, pescador. Pai paralítico, mãe pneumônica, ambos mortos. O doente diz ter sido sadio, bem como seus quatro irmãos. Teve febre amarela, febre palustre e infecção venérea, em moço. Cegueira dupla; poliesclerose visceral; exaltação dos reflexos; língua saburrosa e trêmula. Estado de involução senil instalado: depilado, encanecido, trêmulo, vasos aparentes esclerosados, atitude triste, abatida, calma e profundamente desgostada.

Trabalhava ultimamente em pequenos serviços domésticos, por não lhe permitir mais a cegueira, ajudando na copa a uma criada de sua cunhada. A rapariga divertia-se em fazer pilhérias e graçolas com ele: começou a imaginar que a cunhada não gostava talvez destes modos, talvez supusesse ser ele o provocador, tendo intenções ocultas: desculpou-se mais de uma vez disto. Contudo, parecia que não a acreditavam, julgavam-no devasso, ouviu mesmo chamarem-no tal e outra vez de velho devasso, velho ladrão. Quis a todo o transe sair deste meio, mesmo para um Hospício. Aqui, deprimido e triste, ouve insultarem-no e vê mesmo (o doente é cego dos olhos) pessoas hostis que não reconhece; deseja morrer, pois todos o acusam de ladrão e devasso. Em geral as concepções delirantes giram em torno de assuntos misteriosos que o doente não explica, limitando-se a dizer que todos sabem. Diz que está para o que quiserem, porque se julga pecador. Às vezes o delírio toma feição religiosa, o doente se levanta humildemente, pede perdão a Deus de todos os seus mal feitos, crimes, etc. Pediu para voltar à casa, levaram-no carinhosamente os sobrinhos, mas passados poucos dias, voltou por vontade expressa, pois, o meio doméstico ainda era mais intolerável que o Hospício: continuam as alucinações auditivas, visuais (perguntado, como viu, se não tem olhos, o doente titubeia, volta atrás e responde: parece que vi); o delírio persecutório, a autoacusação, ideias de culpabilidade, perturbações cenestésicas e à profunda depressão psíquica e emotiva que são o fundo do quadro.

\section{Demência precoce, síndromes paranoides, perseguição, grandeza, misticismo}

T.P.O., 25 anos, branco, brasileiro, solteiro, agrimensor. Pais vivos e sãos; quatro irmãos sadios que o doente acusou de geniosos e maus. Em pequeno teve malária; aos 19 anos acidentes venéreos; uso de bebidas espirituosas. Era inteligente e estudioso, suscetível e irritadiço. Estava em Mato Grosso, em 1902, quando apareceu um movimento político revolucionário; convidado por amigos para fazer parte da sedição, recusou-se, censurando-o; isto deu lugar a que lhe chegassem insultos e ameaças, boatos alarmantes e ilusões positivas de assassinato que lhe produziram grande pânico, iniciando o estado atual. Com os irmãos e um cunhado que tentavam dissuadi-lo de seus terrores teve atritos, juntando-se então às vozes estranhas que o ameaçavam às deles que lhe dirigiam desaforos: todos o perseguiam. É um indivíduo forte, bem constituído, sem outra anormalidade somática que uma enorme cabeça quase redonda (diâmetro anteroposterior máximo $200 \mathrm{~mm}$ d. trans. max. $168 \mathrm{~mm}$, índice cefálico - 84, circunf. total 590, curva ant. 295, curv. transv. biauricular 350, curv. ant. posterior 360). Quando entrou para o Hospício tinha ainda boa memória, percepção regular, e distraía-se às vezes, rindo quando o provocavam. Por esta época ideias expansivas que dão testemunho os trechos seguintes de um espírito do doente: 
"Ao Papa da Religião Católica Apostólica Romana comunica T.P.O., nascido a... em..., filho de... e..., etc., que no nascer da manhã do dia mencionado seu avô declarou ser Hipnotista da Terra o recém-nascido, recebendo hipnotismo dos índios Barbados, comunicando-lhes o fato de terem recebido hipnotismo de Júpiter dizendo que era o esperado". "Em 1894 recebeu hipnotismo de Netuno, dizendo que este planeta e o céu dos Santos e no seu satélite esta Deus". Em 1895 recebeu hipnotismo de Júpiter, dizendo que para a Lua vão as almas dos pagãos sem pecado. E assim sucessivamente: o doente recebe de todos os planetas hipnotismo, dizendo coisas diversas e distribuindo os santos, os anjos, os arrependidos, imperdoáveis, pelo nosso sistema solar. Por fim, "a 29 de Outubro recebeu hipnotismo de Júpiter sobre o cometa visto no dia 28, dizendo que é um novo satélite da Terra que tomou o nome de Theotonio (seu nome) e para onde vão as almas dos pagãos menores de três anos, do século $31 \mathrm{em}$ diante, quando o satélite terá tamanho e constituição suficientes". "O documento continua em sua metafísica astronômica e religiosa, com hipnotismos e transmigração das almas, até que o doente o data e assina" "T.P.O., Hipnotizador da Terra". Pouco depois a demência subjacente ao seu delírio fugaz se instalou definitivamente. O doente passeia pelos corredores, deprimido calmo, não se podendo obter mais que sim, não. Visitas da família, trato com o médico, convívio com outros enfermos, não modificam esta obstinada reserva. Entretanto escreve pequenos bilhetes muito simples à mãe, pedindo de vir vêlo e balbucia queixas a espaços: batem-no, maltratam-no, etc.

De sua superioridade, seus hipnotismos não dão indícios presentes.

\section{Involução senil e síndromes paranoides, epilepsia}

A.H.R.C., 52 anos, branco, brasileiro, solteiro, funcionário público. Pai nervoso, irritável, ciumento em extremo, separado duas vezes da mulher, tuberculoso; mãe pródiga, gostando do luxo, morta na Europa para onde fugira em companhia de um amante; tio materno louco; uma irmã morta na infância. Não sabe por que, mas se lembra que, em pequeno, um médico aconselhara a sua família que pusesse água fria na cabeça. Febre amarela e malária graves; blenorragia, cancros venéreos, cancro infectante, sifílides, dores articulares, úlceras; aos 23 anos sobrevieram vertigens, obscurecendo-lhe a vista e a razão, rapidamente; muitas vezes despertava, verificando ter em sonho urinado na cama: muito irascível, genioso, desconfiado, tendo frequentes explosões de cólera, provocadoras de desafetos e inimizades: triviais discussões que tivesse residuavam no ânimo dias seguidos como ideias fixas. "Muitas vezes, diz, a força raciocinar comigo mesmo, chego a atribuir a outrem palavras e fatos que só existem no meu pensamento". Há três anos usou e abusou de alcoólicos, de cerveja especialmente. Dispéptico há muito tempo, sofre horrivelmente dores de cabeça e gastralgias violentas. Nariz adunco e desviado para a direita; orelhas mal conformadas, apresentando pequeno tubérculo em cada lóbulo; sulco nasolabial menos acentuado à direita; profunda decadência orgânica: círculo senil da córnea quase completo, cabelo e barba embranquecidos, bulhas cardíacas fracas, pulso acelerado, esclerose arterial, têmporas flexuosas, língua coberta de saburra branca, tremor fibrilar, hálito fétido, reflexos quase abolidos, insônia.

Já de algum tempo sentia-se mal; os padecimentos do estômago torturavam-no, produzindo um vago mal estar: mudou-se-lhe o humor: andava triste, desanimado, insociável, desconfiado de tudo e suspeitando até achar-se envenenado dois dias antes do sucesso de que é acusado estava 
em casa, quando teve subitamente um pressentimento, saiu para a rua, às tontas, em desalinho, indo procurar auxílio numa farmácia próxima: desde então diz, ficou com uma nuvem sobre o cérebro. Crises de lamúrias, seguidas de outras de mutismo completo: queixa-se a um amigo que julgava ter ingerido uma droga venenosa aos poucos. Uma manhã chamou a amasia com quem vivia, deu-lhe uma certa quantia, recomendando-lhe que vendesse os móveis, entregasse a chave ao senhorio e se mudasse, porque aí não voltaria ele: estava envenenado, ia-se embora. Foi à repartição de que era empregado e aí entrando perguntou a um companheiro quais os sintomas de envenenamento. Depois, reparou que todos os companheiros o olhavam, suspeitou de alguma coisa, naturalmente eles sabiam e não pôde mais conter-se, saiu, armou-se e às 2 da tarde voltou inopinadamente à repartição; não sabia explicar o que iria a fazer; entrou, dirigiu-se para o lugar onde trabalhava o seu íntimo e velho amigo L. M., tirou do bolso o revólver e lho disparou no coração. "Não apontou, diz, se o fizesse talvez não acertasse". Voltando a arma contra si quis atirar, mas os companheiros obstaram-no. Preso, conduzido à delegacia, perguntado por que matara o amigo prorrompeu em desabalado pranto. Daí pra cá é, sobre o assunto, de uma incoerência de memória e de emoção extraordinárias: ora refere os acontecimentos exatamente, deplora desgraça inaudita que causou, "foi um horror, uma loucura", diz; recusa consolações, quer morrer na Detenção, purgando seu crime; ora diz nada ter feito, não se lembra de nada, inteiramente insensível ao fato que lhe atribuem. Isto muitas vezes em dois momentos vizinhos. Muito preocupado, principalmente com a própria saúde: pede que o salvem, queixa-se ainda e pergunta "sou um homem perdido, não é verdade? Não fico mais são!".

O estado demencial se acusa vagarosamente; desmemoriado dos fatos recentes; o estado geral tem melhorado, porém persiste na ideia de que está envenenado, está prestes a morrer; teve uma impulsão em que sem causa arrebentou o vidro numa porta, não explica nem se lembra do fato depois. "O veneno que the deram estragou-lhe o estômago e as artérias, por isso não pode comer nem dormir".

\section{Demência paralítica e síndromes paranoides}

C.F., 50 anos, branco, judeu alemão, naturalizado brasileiro, casado, funcionário consular. Pai morto de uma pneumonia, mãe cardíaca, onze irmãos sadios, dos quais um apenas falecido. Difteria aos 4 anos, blenorragia aos 22, febre amarela ao chegar ao Brasil, câimbra dos escreventes no braço direito e ainda hoje parético e atáxico para os movimentos complicados. Uso de bebidas alcoólicas; fuma excessivamente. Homem de instrução superior, sabendo várias línguas: professou o alemão na Escola Superior de Guerra e foi cônsul na Alemanha (Bremen), na Suécia Noruega (Estocolmo) e ultimamente na Argentina (Salta). Aí começou a doença atual, tendo como causa ocasional um acesso de insolação (?) à que sucedeu agitação, incoerência de propósitos, planos prodigiosos e um furor erótico violento. Conduzido à força para a casa de um parente e daí para o Hospício não se lembra bem onde esteve. É um homem robusto, bem conformado, não apresenta estigmas físicos de degeneração; braço direito descarnado, atrofiado, atáxico, hérnia inguinal esquerda; tremor fibrilar da língua, ataxia dos músculos peribucais tornando disártrica a palavra, atropeladas as sílabas de pronunciação difícil, reflexos rotulianos abolidos; ilusões e alucinações raras. Enfraquecimento da inteligência, memória dos fatos recentes alterada, irritabilidade fácil, sem sentimento de conveniências (revelações pudendas), sem noção exata de sua situação, 
credulidade extrema, contradições e incoerência flagrantes; diz ter um talento vastíssimo, saber 11 línguas, ter tido imensa fortuna, 150.000 contos que perdeu na Bolsa, mas vai ganhar de novo. Em gratidão ao seu médico quer dourá-lo inteiramente, só deixando naturalmente sem douramento os cabelos.

Vai casar os filhos com as filhas de Rotschild. Este banqueiro desejará isto sabendo dos seus planos; estabelecerá casas de café em todas as cidades da Europa e faz os cálculos do preço do quilo do café, torração, impostos, venda a retalho, de sorte a ganhar $17 \$ 860$ em cada quilograma: em tantos milhões de quilos, tal resultado. Faz iguais operações relativamente a outros gêneros do país: fumo, goiabada, abacaxis, etc., realizando assim incalculável fortuna. Poderá com este dinheiro comprar os cafezais de todo o mundo, transplantá-los para o Brasil, fazer aqui o monopólio do café só o exportando torrado para não permitir o novo plantio. Reformará o país, será o vice-presidente da República (não o presidente porque sendo de origem estrangeira a nossa Constituição veda); ocupará todas as pastas ministeriais. Tem planos gigantescos para todas as necessidades públicas: vai acabar com a seca no Ceará, desviando o curso do Rio São Francisco e lançando-o nestas paragens assoladas. Promete embaixadas aos médicos e faz aos internos convites para suas viagens ao redor do mundo. Supõe a um doente do Hospício um cozinheiro extraordinário e que já fez manjares para o imperador Guilherme II. Às vezes ele mesmo é o Kaiser.

As suas ideias de fortuna com o café, etc., são arraigadas e sistematizadas, embora no seu absurdo de grandeza.

\section{$f F$}

